CAPITAL MARKETS 


\title{
Capital Markets
}

\author{
Bernard J. Foley
}

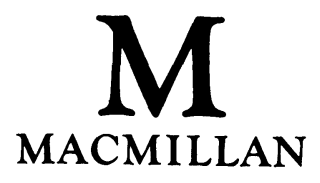


All rights reserved. No reproduction, copy or transmission of this publication may be made without written permission.

No paragraph of this publication may be reproduced, copied or transmitted save with written permission or in accordance with the provisions of the Copyright, Designs and Patents Act 1988, or under the terms of any licence permitting limited copying issued by the Copyright Licensing Agency, 33-4 Alfred Place, London WC1E 7DP.

Any person who does any unauthorised act in relation to this publication may be liable to criminal prosecution and civil claims for damages.

First published 1991

Published by

MACMILLAN EDUCATION LTD

Houndmills, Basingstoke, Hampshire RG21 2XS

and London

Companies and representatives

throughout the world

Edited and typeset by Povey/Edmondson

Okehampton and Rochdale, England

British Library Cataloguing in Publication Data

Foley, Bernard J.

Capital Markets.

1. Great Britain. Capital markets

I. Title

332

ISBN 978-0-333-52333-9 ISBN 978-1-349-21426-6 (eBook)

DOI 10.1007/978-1-349-21426-6 
To my mother Sarah and in memory of my father James Joseph Foley 


\section{Contents}

PREFACE $\quad$ ix

ACKNOWLEDGEMENTS $\quad \mathrm{x}$

LIST OF TABLES Xi

LIST OF FIGURES Xiii

LIST OF ABBREVIATIONS Xiv

INTRODUCTION 1

1 Global Factors 1

2 Market Factors 3

1 THE ROLE AND FUNCTION OF CAPITAL MARKETS 6

1 Introduction 6

2 Company Finance 7

3 Types of Capital 12

4 Raising Capital - Choice of Market 15

5 Raising Capital - Choice of Method 20

2 EQUITIES AND EQUITY MARKETS 27

$\begin{array}{lll}1 \text { Introduction } & 27\end{array}$

2 Equity Valuation $\quad 27$

3 The Nature of Equity Markets 40

4 The UK - The International Stock Exchange (ISE) 41

5 The USA $\quad 52$

6 Japan $\quad 65$

7 The Internationalisation of Equity Markets 69

3 BONDS AND BOND MARKETS

$\begin{array}{lll}1 \text { Introduction } & 75\end{array}$

2 Classifying Bonds $\quad 76$

3 The Market Price of Bonds $\quad 78$

4 Bond Analysis $\quad 80$

5 The Bond Market in the UK 91

6 The Operation of the Gilt-edged Market 96

7 The Bond Market in the USA 104

8 The Japanese Bond Market 109 
4 INTERNATIONAL BOND MARKETS 114

1 Introduction 114

2 Origins of the Eurobond Market 115

3 The Primary Market 120

4 The Secondary Market 126

5 Types of Eurobond - Bond Features 129

6 Swaps 139

5 MARKETS FOR DERIVATIVES 144

1 Introduction 144

2 Forward Markets 145

3 Futures Markets 147

4 Traditional Options 156

5 Traded Options 162

6 Index Options and Index Futures 169

6 THE INSTITUTIONAL INVESTORS 174

1 Introduction 174

2 Investment Institutions 174

3 Insurance Companies 178

4 Pension Funds 180

5 Unit Trusts 183

6 Investment Trusts 186

7 Investment Performance 189

8 The Significance of the Institutions 193

7 REGULATING MARKETS 196

1 Introduction 196

2 The Regulatory Framework in the UK 198

3 The Regulatory Framework in the USA 206

4 The Regulatory Framework in Japan 209

8 CAPITAL MARKETS: SOME CRITICAL QUESTIONS 213

1 Finance for Industry 213

2 'Short Termism' and the Investment Horizon 215

3 Institutional Dominance 216

4 Insider Trading 217

5 New Trading Techniques and Volatility 218

SELECTED BIBLIOGRAPHY $\quad 230$

INDEX 236 


\section{Preface}

This book is primarily written for students but will also prove of interest to anyone who wishes to understand the operation of the world's key capital markets. The intention of the author is to inform and not to intimidate hence the book deliberately addresses a wider audience than those who will become academics or financial analysts. Nevertheless it will provide a useful introduction to undergraduates choosing finance and banking courses as well as those currently engaged on an MBA who do not wish to specialise in finance.

One of the major problems in this area is to find books which offer an adequate mix of theoretical discussion and institutional description. If I have erred toward the latter this reflects the fact that there are a large number of excellent, mainly American, textbooks which can take the reader through the arcane mysteries of Arbitrage Pricing Theory or the Black-Scholes Option Valuation Model. There is no point, except to display a certain academic machismo, in repeating the exercise. The book should therefore be seen as complementary to texts which are more formally concerned with financial analysis. 


\section{Acknowledgements}

Writing a book is merely one stage in a process of production which involves many people, not all of whom are aware of their contribution. I would like to thank the International Stock Exchange, the Association of Investment Trust Companies, NASDAQ International, the Sociéte de Bourses Françaises and the Federation of German Stock Exchanges for their kind responses to my periodic requests. In particular staff at the Liverpool office of the Stock Exchange proved very helpful at a crucial stage in the proceedings. My thanks are also due to the University of Liverpool and Professor Noel Boaden for the study leave which enabled me to make a substantial start, to my editor Steve Rutt, who has been courteous and encouraging throughout, and to Keith Povey, whose suggestions improved the typescript considerably. Finally my deepest gratitude is owed to my wife Polly and our two wonderful sons Tim and Stephen Patrick (S.P.) who had to put up with my absences and the continuous tapping of the word processor during the time that I took to finish this book.

Formby

Bernard Foley 


\section{List of Tables}

1.1 Sources of funds - UK industrial and commercial companies, 1980-9

1.2 Net financing of physical investment (quoted companies), 1949-77

1.3 Sources of funds - US non-financial corporations, 1958-88

1.4 Differences between International Stock Exchange markets

2.1 Major stock exchanges, March 1990

2.3 Comparative income statements - NYSE specialists, 1 st quarter 1987-9 (\$m)

2.4 Number of companies listed on Amex, 1980-8 59

2.5 Size of bid/ask spreads, NASDAQ quotes 63

2.6 ADR issues traded in the USA, 1982-8 69

2.7 Total equity turnover in 1989, selected markets 70

2.8 Costs of trading in various markets - buying and selling as a percentage of initial investment

3.1 International Stock Exchange turnover ( $(\mathrm{m})$ by major category of security, 1980-9

$\begin{array}{llr}\text { 3.2 Average bargain size by value (£), ISE 1980-9 } & 94 \\ 3.3 & \text { US Government Securities - dealers' transactions, 1986-9 } & 104\end{array}$

3.4 New security issues - US corporations, 1987-9 107

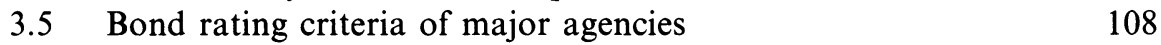

4.1 Location of members of the Association of International Bond Dealers, by centre

4.2 Growth of the Eurobond market, 1963-89 118

4.3 International syndicated credits, 1980-9 119

4.4a Currency composition of new issues in the international bond market, 1985-8

4.4b Currency composition of the international bond market Outstanding stocks, 1982-8

4.5 Eurobond issues - fee structure as a percentage of principal amount

4.6 Comparison of Eurobond and UK domestic bond markets 125

4.7 Total international financing activity, 1985-9 
4.8 Eurobond lead managers 135

4.9 Announced Euronote facilities, 1986-9 138

5.1 Call rates available for traditional options, 10 May $1989 \quad 157$

5.2 Call and put premia for traded options - an example 163

5.3 Change in option premia in relation to share price at expiry 166

6.1 Percentage distribution of shareholding by value - UK equities

6.2 Percentage distribution of shareholding by value - US equities

6.3 UK insurance companies assets at market value, year end 1983-8

6.4 Distribution of UK insurance companies assets, at year end $(\%)$

6.5 Public and private pension fund assets at year end, 1983-8

6.6 Distribution of self administered pension fund assets, at year end (\%)

6.7 Calculating the investment trust discount 188

8.1 Volatility of major stock exchange indices 


\section{List of Figures}

2.1 The relationship between security returns and the market index

3.1 The yield curve $\quad 84$

3.2 Hypothetical yield curves 86

4.1 Interest rate swap 141

8.1 Profit and loss profile of a traded put 226 


\section{List of Abbreviations}

$\begin{array}{ll}\text { ADR } & \text { American Depositary Receipt } \\ \text { AFDB } & \text { Association of Futures Dealers and Brokers } \\ \text { AIBD } & \text { Association of International Bond Dealers } \\ \text { AITC } & \text { Association of Investment Trust Companies } \\ \text { AMEX } & \text { American Stock Exchange } \\ \text { APT } & \text { Automated Pit Trading } \\ \text { BIS } & \text { Bank for International Settlements } \\ \text { CAPM } & \text { Capital asset Pricing Model } \\ \text { CATS } & \text { Computer Assisted Trading System } \\ \text { CBOE } & \text { Chicago Board Options Exchange } \\ \text { CBOT } & \text { Chicago Board of Trade } \\ \text { CD } & \text { Certificate of Deposit } \\ \text { CFTC } & \text { Commodity Futures Trading Commission } \\ \text { CLOB } & \text { Central Limit Order Book } \\ \text { CLOSE } & \text { Central Limit Order Service } \\ \text { CME } & \text { Chicago Mercantile Exchange } \\ \text { DDM } & \text { Dividend Discount Model } \\ \text { DOTS } & \text { Designated Order Turnaround System } \\ \text { DTI } & \text { Department of Trade and Industry } \\ \text { ECD } & \text { EuroCertificate of Deposit } \\ \text { ECP } & \text { EuroCommercial Paper } \\ \text { ECU } & \text { European Currency Unit } \\ \text { EMH } & \text { Efficient Markets Hypothesis } \\ \text { FCM } & \text { Futures Commission Merchant } \\ \text { FIMBRA } & \text { Financial Intermediaries, Managers and Brokers Regulatory } \\ & \text { Association } \\ \text { FOX } & \text { Futures and Options Exchange } \\ \text { FRN } & \text { Floating Rate Note } \\ \text { FSA } & \text { Financial Services Act } \\ \text { GEMM } & \text { Gilt Edged Market Maker } \\ \text { HGSCI } & \text { Hoare Govett Smaller Companies Index } \\ \text { ICCH } & \text { International Commodities Clearing House } \\ \text { IDB } & \text { Inter Dealer Broker } \\ \text { IET } & \text { Interest Equalisation Tax } \\ & \end{array}$




$\begin{array}{ll}\text { ILGS } & \text { Index Linked Government Securities } \\ \text { IMM } & \text { International Money Market } \\ \text { IMRO } & \text { Investment Managers Regulatory Organisation } \\ \text { INS } & \text { Institutional Net Settlement } \\ \text { ISE } & \text { International Stock Exchange } \\ \text { JSDA } & \text { Japanese Securities Dealers Association } \\ \text { LAUTRO } & \text { Life Assurance and Unit Trust Regulatory Organisation } \\ \text { LBO } & \text { Leveraged Buy Out } \\ \text { LDE } & \text { London Derivatives Market } \\ \text { LIFFE } & \text { London International Financial Futures Exchange } \\ \text { LIBOR } & \text { London InterBank Offered Rate } \\ \text { LOCH } & \text { London Options Clearing House } \\ \text { LME } & \text { London Metal Exchange } \\ \text { LTOM } & \text { London Traded Options Market } \\ \text { MATIF } & \text { Marché à Terme International de France } \\ \text { MOF } & \text { Multi Option Facility } \\ \text { NASDAQ } & \text { National Association of Securities Dealers Automatic } \\ & \text { Quotation System } \\ \text { NASDIM } & \text { National Association of Securities Dealers and Investment } \\ & \text { Managers } \\ \text { NIF } & \text { Note Issuance Facility } \\ \text { NMS } & \text { Normal Market Size (UK usage) } \\ \text { NMS } & \text { National Market System (US usage) } \\ \text { NYSE } & \text { New York Stock Exchange } \\ \text { OARS } & \text { Opening Automated Report Service } \\ \text { OTC } & \text { Over the Counter } \\ \text { PSBR } & \text { Public Sector Borrowing Requirement } \\ \text { PSDR } & \text { Public Sector Debt Repayment } \\ \text { RPI } & \text { Retail Price Index } \\ \text { RIE } & \text { Recognised Investment Exchange } \\ \text { RUF } & \text { Revolving Underwriting Facility } \\ \text { SAEF } & \text { SEAQ Automatic Execution Facility } \\ \text { SDR } & \text { Special Drawing Rights } \\ \text { SEC } & \text { Securities and Exchange Commission } \\ \text { SEAQ } & \text { Stock Exchange Automatic Quotation system } \\ \text { SIAC } & \text { Securities Industry Automation Corporation } \\ \text { SICAV } & \text { Société d'Investissement à Capital Variable } \\ \text { SOES } & \text { Small Order Execution Service } \\ \text { SRO } & \text { Self Regulatory Organisation } \\ \text { TAURUS } & \text { Transfer and Automated Registration of Uncertified Stock } \\ \text { TOPIC } & \text { Teletext Output of Price Information by Computer } \\ \text { TSA } & \text { The Securities Association } \\ \text { TSE } & \text { Tokyo Stock Exchange } \\ & \end{array}$

